\title{
Efficient acetylation of primary amines and amino acids in environmentally benign brine solution using acetyl chloride
}

\author{
KAUSHIK BASU ${ }^{\mathrm{a}}$, SUCHANDRA CHAKRABORTY ${ }^{\mathrm{b}}$, ACHINTYA KUMAR SARKAR ${ }^{\mathrm{c}}$ \\ and CHANDAN SAHA ${ }^{\mathrm{b}, *}$ \\ a Department of Chemistry, St. Paul's Cathedral Mission College, Kolkata 700 009, India \\ ${ }^{b}$ Department of Clinical and Experimental Pharmacology, School of Tropical Medicine, Kolkata 700073 , India \\ ${ }^{\mathrm{c}}$ Department of Chemistry, Presidency College, Kolkata 700 073, India \\ e-mail: katichandan@yahoo.co.in
}

MS received 22 May 2012; revised 8 August 2012; accepted 6 November 2012

\begin{abstract}
Acetyl chloride is one of the most commonly available and cheap acylating agent but its high reactivity and concomitant instability in water precludes its use to carry out acetylation in aqueous medium. The present methodology illustrates the efficient acetylation of primary amines and amino acids in brine solution by means of acetyl chloride under weakly basic condition in the presence of sodium acetate and/or triethyl amine followed by trituration with aqueous saturated bicarbonate solution. This effort represents the first efficient use of this most reactive but cheap acetylating agent to acetylate amines in excellent yields in aqueous medium. This is a potentially useful green chemical transformation where reaction takes place in environment-friendly brine solution leading to easy work-up and isolation of the amide derivatives. Mechanistic rationale of this methodology is also important.
\end{abstract}

Keywords. Amines; acetyl chloride; brine; sodium acetate; triethyl amine.

\section{Introduction}

Acetylation offers an efficient and economical means for the identification and characterization of amines as well as to protect an amino functionality in organic synthesis. ${ }^{1}$ Acetyl chloride is one of the most commonly available and cheap acylating agent but its high reactivity and concomitant instability in aqueous medium restricts its use in transformations. As a result moderately reactive acetic anhydride ${ }^{2}$ is the reagent of choice for this purpose, even though this reagent itself is often prepared from acetyl chloride. ${ }^{3}$ A number of conditions including aqueous medium have been put forward for the acylation of amines using acetic anhydride, such as, acetic anhydride in acetic acid, ${ }^{3}$ acetic anhydride in aqueous sodium bicarbonate ${ }^{4}$ solution, and acetic anhydride in the presence of various catalysts such as $\mathrm{RuCl}_{3},{ }^{5} \mathrm{La}\left(\mathrm{NO}_{3}\right)_{3} \cdot 6 \mathrm{H}_{2} \mathrm{O},{ }^{6} \mathrm{NbCl}_{5}{ }^{7}$ and $\mathrm{NaHSO}_{4} \cdot \mathrm{SiO}_{2} \cdot{ }^{8}$ In addition, acetylation of amines has been carried out by using ethyl acetate, ${ }^{9}$ ammonium acetate in acetic acid, ${ }^{10}$ acetic acid in the presence of $\mathrm{Fe}$ (III)-montmorillonite catalyst ${ }^{11}$ and acetic acid as acetylating agent under microwave irradiation. ${ }^{12}$ Few methods of acetylation of amines are known using ace-

*For correspondence tyl chloride of which most common is the use of acetyl chloride in pyridine. ${ }^{13}$ Acetyl chloride has also been used in combination with some fairly exotic reagents such as $\mathrm{ZrOCl}_{2} \cdot 8 \mathrm{H}_{2} \mathrm{O},{ }^{14}$ zinc dust ${ }^{15}$ and thermally decomposed Ni-Fe-hydrotalcite. ${ }^{16}$ However, owing to its aforementioned explosive nature when in contact with water and subsequent rapid hydrolysis, the use of this easily available and cost effective reagent in aqueous medium has proved elusive till date. Acetic anhydride remains the most popular reagent to carry out acetylation reactions in water. Nevertheless in India the availability of this reagent is severely limited, the reason being a Government Order issued under Section 9A of the Narcotic Drugs and Psychotropic Substances Act, 1985 which restricts the free distribution and trading of acetic anhydride and it is considered a controlled substance. ${ }^{17}$ This prompted us to search for an easily available suitable substitute for the said reagent. We reasoned that if the hydrolysis of acetyl chloride can somehow be retarded in water then it can act as a potential acylating agent even in aqueous medium. We have accomplished this by taking acetyl chloride in brine solution where its hydrolysis has been mitigated enough so that it can be used to acetylate aromatic and aliphatic primary amines and amino acids efficiently. Considering the significance of acetylation and environmental 


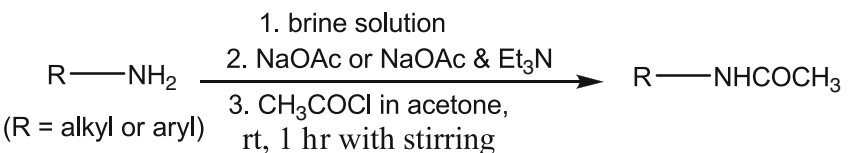

Scheme 1. Acetylation of amines in brine solution.

concerns as well as our interest in achieving organic transformations in water instead of conventional solvents we report here, environmentally benign, economical, brine mediated well-organized and expedient acetylation of primary amines and amino acids using acetyl chloride in presence of a weak base (scheme 1).

\section{Experimental}

Melting points were determined in open capillaries using a Zeal $76 \mathrm{~mm}$ immersion thermometer. Reagentgrade chemicals were purchased from a commercial source and used without further purification. IR spectra were recorded in $\mathrm{KBr}$ discs on Schimadzu FTIR- 8300 and NMR spectra were recorded on Bruker AV 500.

\subsection{General procedure}

2.1a Acetylation of aromatic primary amine: $5 \mathrm{~g}$ $(0.038 \mathrm{~mol}, 1.5 \mathrm{eqv}$.) of sodium acetate trihydrate was dissolved in $50 \mathrm{ml}$ of brine solution ( $36 \%$ aq. solution of sodium chloride). To this was added $0.025 \mathrm{~mol}$ of the aromatic primary amine (water insoluble amines were taken in $\sim 20 \mathrm{ml}$ acetone). Then $2 \mathrm{ml}$ of acetyl chloride ( $0.028 \mathrm{~mol}, 1.1$ eqv.) in $3 \mathrm{ml}$ of acetone was added to the mixture drop-wise with stirring at room temperature. The reaction mixture was stirred for further one hour. Saturated $\mathrm{NaHCO}_{3}$ solution was added till the effervescence ceased. The solution was then acidified with conc. $\mathrm{HCl}$. The sparingly soluble acetyl derivative separated as solid. It was filtered under suction, crystallized from $\mathrm{MeOH} / \mathrm{MeOH}$-water solvent system. Sulphanilic acid, which exists in a zwitterionic form, requires neutralization prior to acetylation. The neutralization was carried out by adding solid $\mathrm{Na}_{2} \mathrm{CO}_{3}$ $(0.025 \mathrm{~mol})$ portion-wise in a warm aqueous suspension of the substrate $(0.025 \mathrm{~mol}$ in $50 \mathrm{ml}$ water $)$. After complete addition of $\mathrm{Na}_{2} \mathrm{CO}_{3}$, a clear solution results, into which requisite amount of $\mathrm{NaCl}$ and sodium acetate trihydrate was dissolved. This was subjected to the usual treatment of acetyl chloride and further work-up.

2.1b Acetylation of aliphatic primary amine: $5 \mathrm{~g}$ $(0.038 \mathrm{~mol}, 1.5 \mathrm{eqv}$. $)$ of sodium acetate trihydrate was dissolved in $50 \mathrm{ml}$ brine solution. Then $0.025 \mathrm{~mol}$ of the aliphatic primary amine and $3.8 \mathrm{ml}(0.028 \mathrm{~mol}, 1.1 \mathrm{eqv}$. triethylamine in $10 \mathrm{ml}$ acetone was added to brine solution and it was followed by drop-wise addition of 1.1 eqv. of acetyl chloride in $3 \mathrm{~mL}$ acetone with continuous stirring. After one hour of stirring, the reaction mixture was acidified with conc. $\mathrm{HCl}$. In each case (i.e., benzyl and cyclohexyl amine), however, the acetyl derivative remained in the solution. The reaction mixture was extracted with $2 \times 50 \mathrm{ml}$ portions of dichloromethane. The combined dichloromethane extract was washed with saturated $\mathrm{NaHCO}_{3}$ solution and dried over anhydrous $\mathrm{Na}_{2} \mathrm{SO}_{4}$. The acetyl derivative was isolated through solvent evaporation. For tryptophan it is noted that sodium acetate is not required for successful acetylation, presumably because of the buffer action of the dipolar form of the amino acid itself.

\subsection{Representative spectral data of acetyl derivatives}

2.2a N-p-tolylacetamide: FTIR (KBr): 3291, 1685, $1610,1552 \mathrm{~cm}^{-1} ;{ }^{1} \mathrm{H}$ NMR $\left(500 \mathrm{MHz}, \mathrm{DMSO}-\mathrm{d}_{6}\right) \delta$ $7.56(\mathrm{~d}, J=7.7 \mathrm{~Hz}, 2 \mathrm{H}), 7.22(\mathrm{~m}, \mathrm{Ar}-2 \mathrm{H} \&-\mathrm{NH})$, 2.36 (s, 3H), 2.14 (s, 3H); ${ }^{13} \mathrm{C}$ NMR (125 MHz, DMSO$\left.\mathrm{d}_{6}\right) \delta 164.23,136.76,133.77,128.03(\times 2), 122.07$ $(\times 2), 24.02,20.07$.

2.2b 4-Acetamidobenzoic acid: FTIR (KBr): 3306, 1684, 1608, $1592 \mathrm{~cm}^{-1}$; ${ }^{1} \mathrm{H}$ NMR $(500 \mathrm{MHz}$, DMSO$\left.\mathrm{d}_{6}\right) \delta 12.42(\mathrm{~s}, 1 \mathrm{H}), 8.32(\mathrm{~d}, \mathrm{~J}=8.7 \mathrm{~Hz}, 2 \mathrm{H}), 7.45(\mathrm{~d}$, $\mathrm{J}=8.7 \mathrm{~Hz}, 2 \mathrm{H}), 2.04(3 \mathrm{H}, \mathrm{s}) ;{ }^{13} \mathrm{C} \mathrm{NMR}(125 \mathrm{MHz}$, DMSO-d $\left._{6}\right) \delta 164.36,163.23,136.76,127.77,128.03$ $(\times 2), 120.07(\times 2), 24.21$.

2.2c 2-Acetamidobenzoic acid: FTIR (KBr): 3386, $1701,1686,1584 \mathrm{~cm}^{-1} ;{ }^{1} \mathrm{H}$ NMR $(500 \mathrm{MHz}$, DMSO$\left.\mathrm{d}_{6}\right) \delta 12.58(\mathrm{~s}, 1 \mathrm{H}), 8.44(\mathrm{~d}, J=8.0 \mathrm{~Hz}, 1 \mathrm{H}), 7.97$ $(\mathrm{d}, J=8.1 \mathrm{~Hz}, 1 \mathrm{H}), 7.40(\mathrm{~m}, \mathrm{Ar}-1 \mathrm{H} \&-\mathrm{NH}), 7.02$ $(\mathrm{t}, 1 \mathrm{H}), 2.08(\mathrm{~s}, 3 \mathrm{H}) ;{ }^{13} \mathrm{C}$ NMR $(125 \mathrm{MHz}$, DMSO$\left.\mathrm{d}_{6}\right) \delta 165.16,164.29,140.16,130.37,128.03,127.58$, 120.07, 118.22, 23.31 .

2.2d $N, N^{\prime}-(1,4-$ phenylene)diacetamide: FTIR (KBr): $3301,1708,1664,1589 \mathrm{~cm}^{-1} ;{ }^{1} \mathrm{H}$ NMR $(500 \mathrm{MHz}$, DMSO-d $\left._{6}\right) \delta 7.54(\mathrm{~m}, 2 \mathrm{H}), 7.21(\mathrm{~m}, 2 \mathrm{H}), 2.06(\mathrm{~s}, 6 \mathrm{H})$; ${ }^{13} \mathrm{C}$ NMR $\left(125 \mathrm{MHz}, \mathrm{DMSO}-\mathrm{d}_{6}\right) \delta$ 164.74(×2), 134.57 (×2), $122.00(\times 2), 121.02(\times 2), 24.31(\times 2)$.

2.2e Sodium 4-acetamidobenzenesulphonate: FTIR (KBr): 3401, 1705, 1683, $1584 \mathrm{~cm}^{-1} ;{ }^{1} \mathrm{H}$ NMR $\left(500 \mathrm{MHz}, \mathrm{DMSO}_{-} \mathrm{d}_{6}\right) \delta 7.65(\mathrm{~d}, J=8.5 \mathrm{~Hz}, 2 \mathrm{H}), 7.22$ $(\mathrm{d}, J=8.5 \mathrm{~Hz}, 2 \mathrm{H}), 2.48$ (s, 3H); ${ }^{13} \mathrm{C} \mathrm{NMR}(125 \mathrm{MHz}$, 
DMSO $\left.-\mathrm{d}_{6}\right) \delta 166.84,133.18,127.00(\times 3), 121.79$ $(\times 2), 23.31$.

2.2f N-benzylacetamide: FTIR (KBr): 3297, 1648, $1555 \mathrm{~cm}^{-1} ;{ }^{1} \mathrm{H}$ NMR $\left(500 \mathrm{MHz}, \mathrm{DMSO}-\mathrm{d}_{6}\right) \delta 7.45-$ $7.23(\mathrm{~m}, 5 \mathrm{H}), 3.84(\mathrm{~s}, 2 \mathrm{H}), 2.04(\mathrm{~s}, 3 \mathrm{H}) ;{ }^{13} \mathrm{C} \mathrm{NMR}$ $\left(125 \mathrm{MHz}, \mathrm{DMSO}-\mathrm{d}_{6}\right) \delta 167.54,137.18,128.60(\times 2)$, $126.75(\times 2), 124.39,52.34,24.21$.

2.2g 2-Acetamido-3-(1H-indol-3-yl)propanoic acid: FTIR (KBr): 3358, 3341, 1721, 1712, 1629, $1552 \mathrm{~cm}^{-1}$; ${ }^{1} \mathrm{H}$ NMR (500 MHz, DMSO-d $\left.{ }_{6}\right) \delta 12.57$ (br, 1H), 10.83 $(\mathrm{s}, 1 \mathrm{H}), 8.14(\mathrm{~d}, \mathrm{~J}=7.5 \mathrm{~Hz}, 1 \mathrm{H}), 7.52(\mathrm{~d}, J=8.0 \mathrm{~Hz}$, $1 \mathrm{H}), 7.32(\mathrm{~d}, J=8.0 \mathrm{~Hz}, 1 \mathrm{H}), 7.13(\mathrm{~s}, 1 \mathrm{H}), 7.06(\mathrm{t}$, $1 \mathrm{H}), 6.97(\mathrm{t}, 1 \mathrm{H}), 4.45$ (q, 1H), 3.15, $2.98(\mathrm{~m}, 2 \mathrm{H}, \mathrm{Ar}-$ $\mathrm{CH}_{2}$, diastereotopic), 2.11 (s, 3H); ${ }^{13} \mathrm{C}$ NMR $(125 \mathrm{MHz}$, DMSO-d $\left._{6}\right) \delta 169.23,164.19,136.16,130.37,123.03$, $122.28,121.27,120.29,112.17,110.56,55.35,29.76$, 24.50 .

\section{Results and discussion}

Primary amine or amino acid (acetone solution or neat substrate in case of water soluble amines) was added to brine (scale: $1 \mathrm{~g}$ of sodium chloride in $3 \mathrm{ml}$ water) containing sodium acetate for aromatic amines or sodium acetate along with triethyl amine for aliphatic amines and then 1.1 equivalents of acetyl chloride in acetone (1:1) was added drop-wise with stirring. The desired product was finally obtained by treating the reaction mixture with saturated bicarbonate solution followed by acidification with mineral acid.

This methodology has two important mechanistic rationales. (i) In order to gain insight into the role of the brine, it was assumed that the high concentration of chloride ion, a better nucleophile than water, in the reaction mixture resists the hydrolysis of acetyl chloride, a most reactive acetyl derivative and thus its selectivity is enhanced. The underlying principle was supported by the fact that when the reaction was carried out only in water (instead of brine) the yield of acetyl derivative decreased radically (table 1), as expected because of the ready hydrolysis of the acylating agent in water. (ii) The $\mathrm{pK}_{\mathrm{aH}}$ of aromatic amines are in the region of 5.0. As a result, the use of sodium acetate through its buffer action escorts the more nucleophilic amino group to react with acetyl chloride. The hydrogen chloride $(\mathrm{HCl})$ liberated during the reaction reacts with sodium acetate to form acetic acid in situ and thus the reaction medium is buffered due to the presence of $\mathrm{NaOCOCH}_{3}-\mathrm{CH}_{3} \mathrm{COOH}$. After completion of the reaction, $\mathrm{pH}$ of the medium was found to be around 6.0.
Table 1. Percentage yield of the acetylated product in different reaction medium.

\begin{tabular}{lcc}
\hline Sl. No. Substrate & Reaction medium & Yield (\%) \\
\hline Brine medium & $\begin{array}{c}\text { Bater-NaOAc medium } \\
\text { Brine-NaOAc medium }\end{array}$ & $\begin{array}{c}08 \\
\text { No product }\end{array}$ \\
2. & $\begin{array}{c}\text { Brine medium } \\
\text { Water-NaOAc medium } \\
\text { Brine-NaOAc medium }\end{array}$ & 06 \\
&
\end{tabular}

The basicity of aliphatic amines $\left(\mathrm{pK}_{\mathrm{aH}} c a .10 .0\right)$ is however higher than that of aromatic amines. This is responsible for the very low yields of the acetylated products for aliphatic amines under the usual reaction condition using sodium acetate, where protonation of the amine results in subsequent loss of nucleophilic reactivity of the basic nitrogen centre. To circumvent this problem we have utilized triethyl amine (TEA) $\left(\mathrm{pK}_{\mathrm{aH}}\right.$ 10.75 ) as proton scavenger along with sodium acetate (which maintains the buffer action) for acetylation of aliphatic amines. This rationale was justified by the fact that when the acetylation of aliphatic amines is carried out in the presence of triethyl amine the yield is significantly improved (table 2 ).

It is evident from table 2 that the presence of both $\mathrm{NaOAc}$ and TEA is essential to obtain a good yield of the acetylation of aliphatic primary amine. This result points to a probable combined buffer action by the conjugate acid of TEA and $\mathrm{NaOAc}$, thereby the amino group of the substrate remains in free, nucleophilic state which is conducive for acetylation. This is, of course,

Table 2. Role of triethylamine (TEA) on percentage yield.

\begin{tabular}{|c|c|c|c|}
\hline $\begin{array}{l}\text { Sl. } \\
\text { No. }\end{array}$ & Substrate & Reaction medium & $\begin{array}{l}\text { Yield } \\
(\%)\end{array}$ \\
\hline \multirow{3}{*}{1.} & & $\begin{array}{l}\text { Brine-NaOAc medium } \\
\text { in the absence of TEA }\end{array}$ & 11 \\
\hline & & $\begin{array}{l}\text { Brine-TEA medium } \\
\text { in the absence of } \mathrm{NaOAc}\end{array}$ & 52 \\
\hline & & $\begin{array}{l}\text { Brine-NaOAc medium } \\
\text { in the presence of TEA }\end{array}$ & 79 \\
\hline \multirow{3}{*}{2.} & & $\begin{array}{l}\text { Brine-NaOAc medium } \\
\text { in the absence of TEA }\end{array}$ & 10 \\
\hline & & $\begin{array}{l}\text { Brine-TEA medium } \\
\text { in the absence of } \mathrm{NaOAc}\end{array}$ & 50 \\
\hline & & $\begin{array}{l}\text { Brine-NaOAc medium } \\
\text { in the presence of TEA }\end{array}$ & 75 \\
\hline
\end{tabular}


unnecessary in case of aromatic amines as the $\mathrm{N}$ centre is less basic in those substrates.

It is to be noted that in case of sulphanilic acid the sodium salt of the acetyl derivative is separated out at the completion of reaction, presumably due to common ion $\left(\mathrm{Na}^{+}\right)$effect. The zwitterionic form of sulphanilic acid also requires prior neutralization before the acetylation can be performed (vide experimental section for details). In all the cases examined, the derivatives were crystallized from methanol/methanol-water/water and identified by comparing with authentic samples. The results are summarized in the table 3 .

Table 3. Acetylation of primary amines and amino acids.

Base used (eqv. amount)
Of acetyl derivative, $\left.{ }^{\circ} \mathrm{C}\right)$
Sodium acetate (1.5)


Table 3. (continued)

S1.

No.

9.<smiles>Nc1ccccc1Cl</smiles>

10.<smiles>Nc1cccc([N+](=O)[O-])c1</smiles>

11.<smiles>Nc1ccc([N+](=O)[O-])cc1</smiles>

12.<smiles>COc1ccc(N)cc1</smiles>

13.<smiles>COc1ccccc1N</smiles>

14.<smiles>Nc1ccc(Br)cc1</smiles>

15.<smiles>Nc1cccc(O)c1</smiles>

16.*<smiles>CC(=O)Nc1ccc(N)cc1</smiles>

17.<smiles>Cc1ccc(N)cc1C</smiles>

Yield (\%), (Mp/lit. mp

Base used (eqv. amount) of acetyl derivative, ${ }^{\circ} \mathrm{C}$ )

Sodium acetate (1.5)

$75,(87 / 87)$

Sodium acetate (1.5)

$82,(150 / 155)$

Sodium acetate (1.5)

$78,(212 / 215)$

Sodium acetate (1.5)

$79,(127 / 127)$

Sodium acetate (1.5)

$80,(84 / 84)$

Sodium acetate (1.5)

$93,(165 / 167)$

Sodium acetate (1.5)

$84,(145 / 148)$

Sodium acetate (1.5)

$80,(300 / 304)$

Sodium acetate (1.5)

82, (98/98) 
Table 3. (continued)

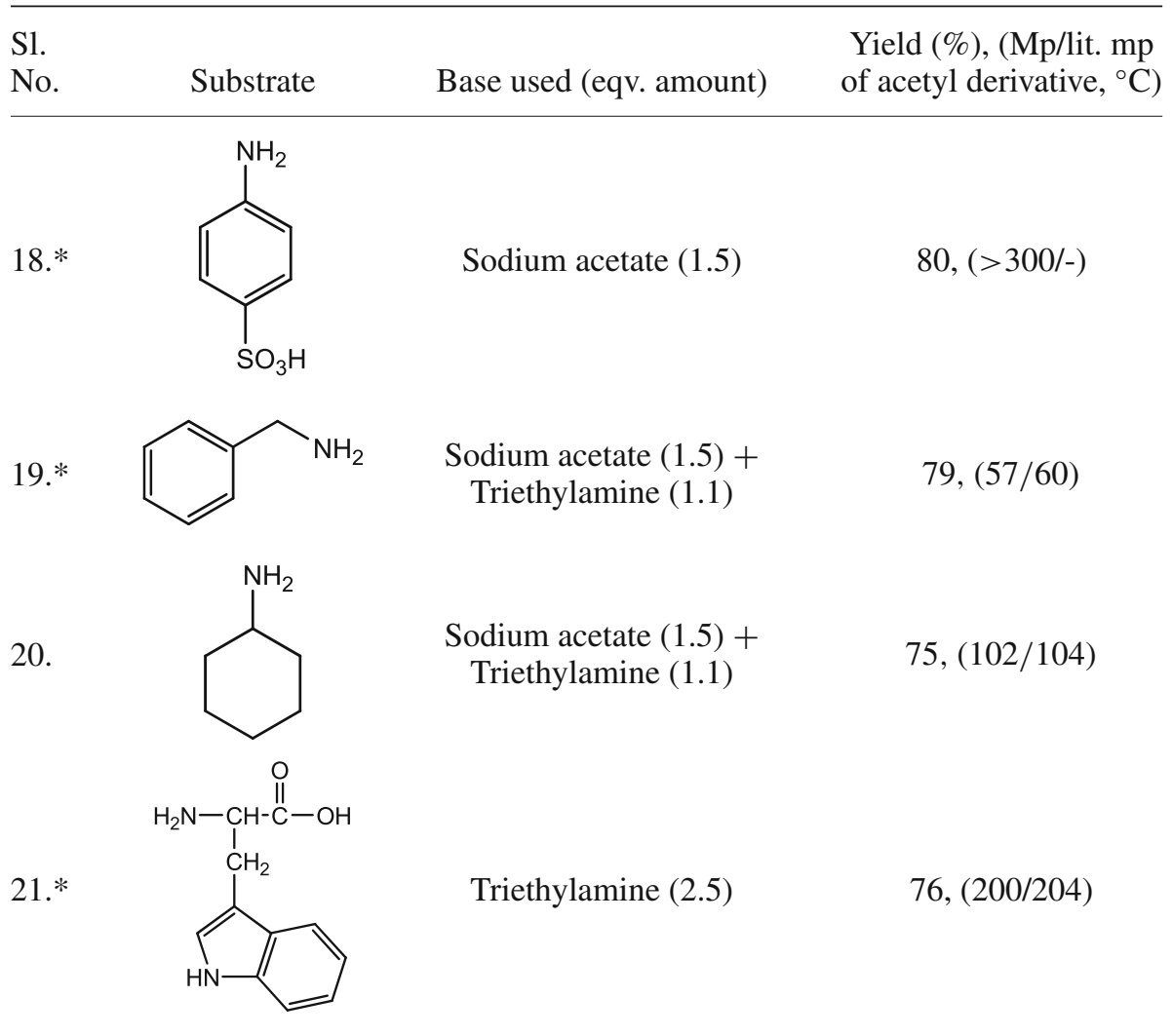

*Spectral data is furnished for these acetyl derivatives

Here it is important to observe the chemoselective $\mathrm{N}$-acetylation in preference over the possible $O$ acetylation (e.g., aminophenol), and $C$-acetylation (in case of aromatic amines). In addition, we wish to report that the reaction was also successful when carried out in large scale (with $0.25 \mathrm{~mol}$ of the starting amine) and the yield of the isolated anilide increased considerably (5\% increase in yield with aniline as the substrate).

\section{Conclusion}

In this report, we have described a very simple, inexpensive, high yielding, non-toxic, environment-friendly brine mediated method for the acetylation of amines and amino acids using most reactive acetyl chloride. This green chemical acetylation also features easy work-up and isolation of acetamides in excellent yield. The transformation is potentially useful in protecting group chemistry as well as for the purpose of characterization and identification of amino compounds by methods of acetyl derivative formation. This method presents a viable alternative to the use of acetic anhydride, the availability of which is restricted in India. This is also the first report of efficient acetylation using the most reactive acetyl chloride in aqueous environ- ment. In addition, from the academic point of view, the use of acetyl chloride in brine solution along with $\mathrm{NaOAc/triethyl} \mathrm{amine} \mathrm{is} \mathrm{undoubtedly} \mathrm{an} \mathrm{interesting}$ finding.

\section{Acknowledgements}

We thank Prof. Krishnangshu Roy, Director and Prof. Santanu Tripathi, Head of the Department of Clinical and Experimental Pharmacology, School of Tropical Medicine, Kolkata for their interest in the work. We also thank Dr. Gautam Chattopadhyay, Post-Graduate Department of Chemistry, Presidency College for insightful discussions. We thank the Council of Scientific and Industrial Research (CSIR), New Delhi, India for providing a Senior Research Fellowship (Grant No. 09/951(0001)/2008-EMR-I) to one of the authors (SC).

\section{References}

1. Greene T W and Wuts P G M 1999 Protective groups in organic synthesis, 3rd edn (New York: John Wiley and Sons Ltd.)

2. Furniss B S, Hannaford A J, Smith P W G and Tatchell A R (eds) 2006 Vogel's textbook of practical organic chemistry, 5th edn (London: Pearson Education) 
3. Furniss B S, Hannaford A J, Rogers V, Smith P W G and Tatchell A R (eds) 1978 Vogel's textbook of practical organic chemistry, 4th edn (London: ELBS/Longman) p. 684

4. Naik S, Bhattacharjya G, Kavala V R and Patel B K 2004 ARKIVOC 55

5. De S K 2004 Tetrahedron Lett. 452919

6. Reddy T S, Narasimhulu M, Suryakiran N, Mahesh K C, Ashalatha K and Venkateswarlu Y 2006 Tetrahedron Lett. 476825

7. Yadav J S, Narsaiah A V, Basak A K, Goud P R, Sreenu D and Nagaiah K 2006 J. Mol. Cat. A: Chemical 25578

8. Das B and Thirupathi P 2007 J. Mol. Cat. A: Chemical 26912

9. Heravi M M, Bakhtiari K, Javadi N M, Oskooie H A and Bamoharram F F 2007 Monatshefte für Chem. 138445
10. Prasad H S, Srinivasa G R and Gouda D C 2005 Synth. Coтmun. 351189

11. Choudary B M, Bhaskar V, Lakshmi Kantam M, Rao K K and Raghavan K V 2001 Catal. Lett. 74207

12. (a) Bahmachari G, Laskar S and Sarkar S 2010 Ind. J. Chem. 49B 1274; (b) Krishna Mohan K V V, Narendar N and Kulkarni S J 2006 Green Chem. 8368

13. Olson V R and Feldman H B 1937 J. Am. Chem. Soc. 59 2003

14. Ghosh R, Maiti S and Chakraborty A 2005 Tetrahedron Lett. 46147

15. Pasha M A, Reddy M B M and Manjula K 2010 Eur. $J$. Chem. 1385

16. Choudhary V R and Dumbre D K 2011 Catal. Commun. 121351

17. http://narcoticsindia.nic.in/NDPSACT.htm. Accessed 22 May 2012 